\title{
Comparison of some New Maize Hybrids Response to Mineral Fertilization and some Nanofertilizers
}

\author{
Gomaa, M. A., F. I. Radwan, E. E. Kandil and D. H. H. Al- Challabi ${ }^{1}$
}

\begin{abstract}
Maize (Zea mays, L.) production considered as one of the most important creal crops in Egypt to face the human and animal essential needs. In this respect, to increase the maize production, some continuous extension efforts had been done at both horizontal and vertical levels to study response of some new maize hybrids to mineral and nanofertilization. Two field experiments were conducted at the Experimental Farm of Faculty of Agriculture (SabaBasha), Alexandria University, Abess Region, Egypt, during two summer seasons of 2016 and 2017. A split plot design in three replicates was used. Main plots contain of four fertilization treatments "Mineral fertilizer ( $K$ and $P$ ) as foliar application, Mineral fertilizer ( $K$ and $P$ ) in soil, application of Nano- fertilizer ( $K$ and $P$ ) as foliar application, and mineral as soil application (K AND P) + nano- fertilizer as foliar (K AND P)". While, sub-plots contained three yellow maize hybrids "Single Cross 162 (S.C. 162), Single Cross 166 (S.C. 166) and Single Cross 168 (S.C.168)". The obtained results revealed that application of mineral fertilizer in the soil + foliar application of nano- fertilizer recorded the highest value of plant height, ear length and number of rows/ear, number of grains/row, number of grains/ear, 100- grain weight, biological, straw and grain yield. However, S.C.168 hybrid gave the highest grain yield and its components in comparison with other hybrids. On the other hand, interact maize hybrid S.C. 168 with foliar application of Nanofertilizers ( $K$ and $P$ ) and soil application of mineral fertilization by $K$ and $P$ increased yield and its components of maize crop under the study Alexandria Governorate conditions.
\end{abstract}

Key words: maize; yield; mineral; Nano; fertilization; hybrids; yellow

\section{INTRODUCTION}

Maize (Zea mays L.) is one of the main grain crops after wheat and rice in the world (Gerpacio and Pingali, 2007). Maize is one of the most important cereal crops especially in Egypt, whether a great attention has been paid to increase its total production. The area devoted to maize cultivation in Egypt is about 1.8 million feddans (FAO, 2014) and the average yield of maize reached about $25.70 \mathrm{ardb}$./fed. Whereas in the newly reclaimed desert area agronomic practices such as application of bio- organic and/or mineral fertilization, irrigation and new hybrids are used.

\footnotetext{
${ }^{1}$ Plant production Department, The Faculty of Agriculture (Saba Basha), Alexandria University, Egypt Received August 15, 2017, Accepted September 6, 2017
}

Potassium (K) helps in photosynthesis process, controlling water storage and stomata opening in leaves (Zhang and Wang, 2005). Using nano- potash fertilizer as the source of potassium in rice, which resulted in increase number of grains per panicle and also the amount compared to muriate of potash was less. They revealed that coating wheat and corn by nano and slow release fertilizers of the same to crops has increased grain yield as well as effective recovery of $\mathrm{N}$ fertilizer (Subbarao et al., 2013).

Modern hybrids of maize respond to $\mathrm{K}$ differently due to difference in its uptake, translocation, growth and utilization (Minjian et al., 2007). Foliar application of elements gave significant effect on yield attributes and protein content in some wheat cultivars compared with control treatment (Mekkei and El Haggan, 2014).

Nano- fertilizers had an important role where the ancient chemical fertilizers are replaced with nano and bio fertilizers with their efficiency and environment friendly nature. Primary use of adding is fast uptake of nutrients from the soil and giving better, faster yield. The symbiotic exchange between soil and the plant system is very efficient. When the same is applied in slow and efficient way all the required nutrients is taken up by the plant and restores the required and efficient energy in it for which the yield increases drastically.

Main element nitrogen is needed in abundant and uptake of this itself causes many problems to the plants (Kulzer and Orrit, 2004).

Nanotechnology can present solution to increasing the value of agricultural products and environmental problems. With Using of Nano-particles and Nanopowders, we can produce controlled or delayed releasing fertilizers. Nano-particles have high reactivity because of more specific surface area, more density of reactive areas, or increased reactivity of these areas on the particle surfaces. These features simplify the fertilizers and pesticides absorption that produced in Nano scale (Anonymous, 2009).

Nano- fertilizers mainly delay the release of the nutrients and extend the fertilizer effect period. Obviously, there is an opportunity for nanotechnology to have a significant influence on energy, the economy and the environment, by improving fertilizers (Naderi and Shahraki, 2013). Nano-fertilizers amied to release their 
shipment in a controlled manner (slowly or quickly) in reaction to different signals such as heat, moisture and etc. On the other hand, under nutrient limitation, crops carbonaceous compounds into rhizosphere to enable biotic mineralization of $\mathrm{N}$ and/or $\mathrm{P}$ from soil organic matter and of $\mathrm{P}$ associated with soil inorganic colloids. Since, these root exudates can be considered as environmental signals and be selected to prepare nanobiosensors that will be incorporated into novel Nano fertilizers (Al-Amin and Jayasuriya, 2007, Sultan et al., 2009).

Foliar application of nao- fertilizer at two or three stages (vegetative, flowering or filling) increased yield and yield components of faba bean in both seasons (Gomaa et al., 2016). Plant height, yield and its components of wheat were increased by foliar application of nano- fertilizer during both growing seasons. Meanwhile, the applied mineral fertilizer, alone; gave the lowest mean values of the studied traits (Kandil and Marie, 2017)

The objective of this study is to estimate some maize hybrids productivity under effect of mineral- nano phosphorus and potassium fertilization.

\section{MATERIALS AND METHODS}

Two field experiments were carried out at the Experimental Farm of Faculty Agriculture (SabaBasha), Alexandria University, Abess Region, Egypt, during two summer seasons of 2016 and 2017. This study goaled to investigate response of three maize hybrids to mineral and nano phosphorus and potassium fertilization.

Soil texture was clay loam. A surface sample (0-30 $\mathrm{cm})$ was collected before planting to identify some physical and chemical properties of this soil as shown in Table (1) according to Klute (1986).

The preceding crop was Egyptian clover (Trifoluim alexandrinum L.) in the first and second season, respectively.

The experimental design was a split plot in three replicates. Main plots contained four fertilization treatments "Mineral fertilizer ( $\mathrm{K}$ and $\mathrm{P})$ as foliar application, Mineral fertilizer $(\mathrm{K}$ and $\mathrm{P})$ as soil application, Nano- fertilizer ( $\mathrm{K}$ and $\mathrm{P})$ as foliar application and Mineral as soil application ( $\mathrm{K}$ and $\mathrm{P})+$ nano- fertilizer as foliar (K AND P)". Sub-plots contain three yellow maize hybrids "Single Cross 162 (S.C. 162), Single Cross 166 (S.C. 166), Single Cross 168 (S.C.168)",

Phosphorus fertilizer was added at rate of $57.6 \mathrm{~kg}$ $\mathrm{P}_{2} \mathrm{O}_{5} /$ ha in the form of calcium mono phosphate $(15.5 \%$ $\mathrm{P}_{2} \mathrm{O}_{5}$ ) just before sowing. Potassium fertilizer was applied before sowing (during seedbed preparation) at rate of $120 \mathrm{~kg} \mathrm{~K} \mathrm{~K}_{2} \mathrm{O} / \mathrm{ha}$., in the form of potassium sulphate $\left(48 \% \mathrm{~K}_{2} \mathrm{O}\right)$.

Table 1. Some physical and chemical properties of the experimental soil in 2016 and 2017 seasons

\begin{tabular}{|c|c|c|}
\hline \multirow[t]{2}{*}{ Soil properties } & \multicolumn{2}{|c|}{ Season } \\
\hline & 2016 & 2017 \\
\hline \multicolumn{3}{|l|}{ A) Mechanical analysis: } \\
\hline Clay $\%$ & 38.00 & 37.00 \\
\hline Sand $\%$ & 32.00 & 33.00 \\
\hline Silt \% & 30.00 & 30.00 \\
\hline Soil texture & \multicolumn{2}{|c|}{ Clay loam soil } \\
\hline \multicolumn{3}{|l|}{ B) Chemical properties } \\
\hline$\overline{\mathrm{PH}(1: 1)}$ & 8.20 & 8.31 \\
\hline E.C. $(\mathrm{ds} / \mathrm{m})$ & 3.60 & 3.70 \\
\hline \multicolumn{3}{|c|}{ 1) Soluble cations $(1: 2)(\mathrm{cmol} / \mathrm{kg}$ soil $)$} \\
\hline $\mathrm{K}^{+}$ & 1.52 & 1.54 \\
\hline $\mathrm{Ca}^{++}$ & 9.40 & 8.70 \\
\hline $\mathrm{Mg}^{++}$ & 15.00 & 15.60 \\
\hline $\mathrm{Na}^{++}$ & 10.50 & 11.00 \\
\hline \multicolumn{3}{|c|}{ 2) Soluble anions $(1: 2)(\mathrm{cmol} / \mathrm{kg}$ soil $)$} \\
\hline $\mathrm{CO}_{3}^{--}+\mathrm{HCO}_{3}^{-}$ & 5.20 & 5.30 \\
\hline $\mathrm{Cl}^{-}$ & 18.00 & 19.00 \\
\hline $\mathrm{SO}_{4}^{-}$ & 13.50 & 12.50 \\
\hline Calcium carbonate (\%) & 6.50 & 7.00 \\
\hline Total nitrogen $\%$ & 1.00 & 0.91 \\
\hline Available phosphorus $(\mathrm{mg} / \mathrm{kg})$ & 3.70 & 3.55 \\
\hline Organic matter $(\%)$ & 1.41 & 1.40 \\
\hline
\end{tabular}


Mineral nitrogen fertilizer was given in two dose in a form of urea $(46 \% \mathrm{~N})$ after thinning before the first and the second irrigation at rate of $288 \mathrm{~kg} \mathrm{~N} / \mathrm{ha}$.

Nano-compound namely; Potacrystal and Phospho one at rate of $1 \mathrm{~cm} / 1$ water added as foliar application and mineral (Mil Agro Crop Max) P and K was applied at rate of $1200 \mathrm{~g} / \mathrm{ha} / \mathrm{spray}$ as foliar application at two times i.e., after 45 and 65 days from sowing. Analysis of the three fertilizer compounds are shown in Tables $(2$ and 3).

Each sub plot area was $10.80 \mathrm{~m}^{2}$ included 6 ridges each $3 \mathrm{~m}$ in length and $0.60 \mathrm{~m}$ in width the distance between hills was $25 \mathrm{~cm}$. The grains of the tested three yellow maize hybrids were obtained from Maize Research Section Agriculture Research Center, Ministry of Agriculture. The grains were sown on May $8^{\text {th }}$ and $1^{\text {st }}$ April of 2016 and 2017 seasons, respectively.

Studied traits, i.e. data include plant height at harvest $(\mathrm{cm})$, ear length $(\mathrm{cm})$, grains number/row, rows number /ear, grains number /ear, 100 - grain weight (g), grain yield, straw yield, biological yield (ton/ha.), and harvest index (\%) were recorded at harvest time after 120 days from planting. Three inner rows, were taken from each sub-plot to determine grain yield on the basis of $15.5 \%$ moisture.

All collected data were subjected to analysis of variance according to Gomez and Gomez (1984). All statistical analysis were performed using analysis of variance technique using CoStat computer software package (CoStat, Ver. 6.311., 2005). The least significant difference (LSD at 0.05) was used to compare the treatment means.

\section{RESULTS AND DISCUSSION}

The obtained data in Table (4) reveals the effect of application of Nano and mineral fertilization on plant height, ear length and number of rows/ear for three yellow maize hybrids and their interaction during 2016 and 2017 seasons.

The data in Table (4) shows that application of nano and mineral fertilization, significantly, influenced plant height, ear length and number of rows/ear during both growing seasons. The highest values of plant length at harvest, ear length and number of rows/ear (168.87 and $193.73 \mathrm{~cm}),(17.44$ and $18.42 \mathrm{~cm})$ and $(15.10$ and 15.11 rows) were recorded with application of mineral fertilizer in the soil + foliar application of nanofertilizer followed by foliar nano- fertilization treatment as compared with other treatments. Meanwhile, the lowest ones (133.59 and $165.99 \mathrm{~cm}),(14.49$ and 15.12 $\mathrm{cm})$ and (14.00 and 14.00 rows) were recorded with foliar mineral fertilizer alone during two growing seasons. These results are in agreement with those obtained by Gholami et al. (2013), Farnia and Omidi (2 015) and Vafa et al. (2015) who stated positive response of crop yield to foliar application of nano- fertilizer.

Concerning maize hybrids, data in Table (4) showed significant differences among the three hybrids in both growing seasons. The hybrid "S.C. 168" recorded the highest values for plant height $(156.25$ and $188.65 \mathrm{~cm})$, ear length (15.40 and $15.74 \mathrm{~cm})$ and number of rows/ear, (14.68 and 14.68 rows), while "S.C. 162" hybrid gave the lowest values of plant height, ear length and number of rows/ear $(149.33$ and $174.39 \mathrm{~cm}),(14.00$ and 14.00 rows) and (34.67 and 36.62 grains) in two growing seasons.

Table 2. Analysis of nano fertilizer (as foliar application)

\begin{tabular}{lcc}
\hline \multirow{2}{*}{ Element } & \multicolumn{2}{c}{ Compound name (nano- fertilizer) } \\
\cline { 2 - 3 } & Potacrystal & Phospho one \\
\hline $\mathrm{K}_{2} \mathrm{O}$ & $36.0 \%$ & $28.0 \%$ \\
$\mathrm{P}_{2} \mathrm{O}_{5}$ & $2.0 \%$ & $40.0 \%$ \\
$\mathrm{Amino}$ acids & $5.0 \%$ & $5.0 \%$ \\
Seaweed extarcts & - & $2.0 \%$ \\
Vitamines & $1.0 \%$ & $1.0 \%$ \\
Total nitrogen & $5.0 \%$ & $5.0 \%$ \\
Micronutrients $(\mathrm{Br}, \mathrm{Zn}, \mathrm{Mn}, \mathrm{Co}$, and $\mathrm{Mo})$ & $2.0 \%$ & - \\
\hline
\end{tabular}

Table 3. Analysis of mineral fertilizer (as foliar application)

\begin{tabular}{lc}
\hline Element & Mil Agro Crop Max (mineral fertilizer) \\
\cline { 2 - 2 } & w/w \\
\hline $\mathrm{K}_{2} \mathrm{O}$ & $56.0 \%$ \\
$\mathrm{P}_{2} \mathrm{O}_{5}$ & $43.0 \%$ \\
Total nitrogen & $0.0 \%$ \\
Micronutrients $(\mathrm{Br}, \mathrm{Zn}$, and $\mathrm{Mn})$ & $1.0 \%$ \\
\hline
\end{tabular}


Table 4. Plant attributes of three maize hybrids as influenced by soil and foliar mineral and nanofertilizer and their interaction during 2016 and 2017 seasons

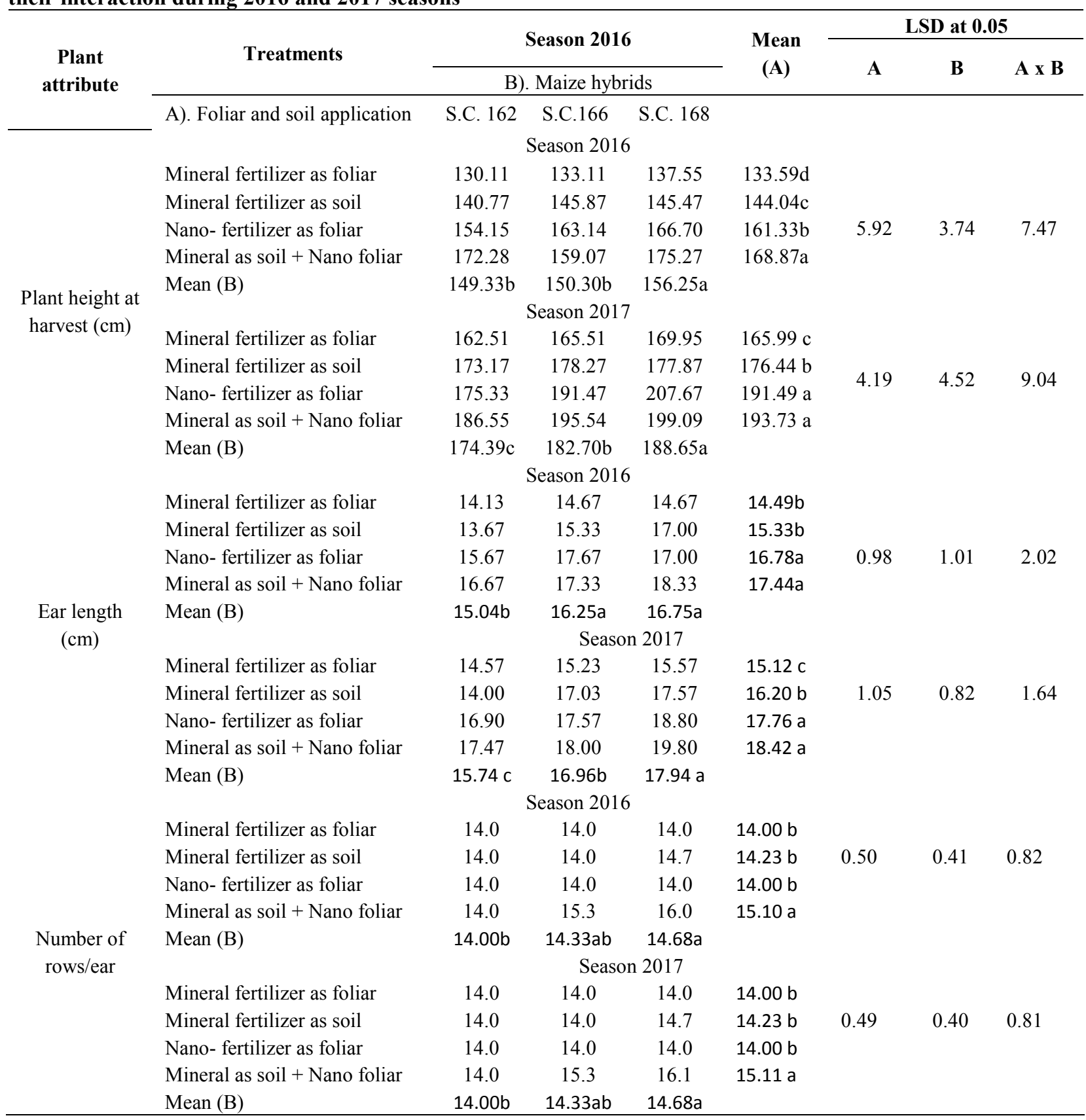

Mean values in the same column/row marked with the same letter are not significantly different at 0.05 level of probability.

These differences among hybrids are mainly due to genetic differences makeup between the three cultivars. These results were harmony with those obtained by Khaliq et al. (2009), Nosser (2011), Kandil (2013) and Gomaa et al. (2016).

The interaction between mineral and nano fertilizers and maize hybrids showed a significant effect on plant height, ear length and number of rows/ear in the first and second growing seasons (Table 4). Likewise, "mineral fertilizer as soil application with foliar application of nano- fertilizer" or "nano- fertilizer alon" combined with "S.C. 168" hybrid gave the highest mean values of plant height (175.27 and $207.67 \mathrm{~cm}$ ), ear length (18.33 and 19.80 rows) and number of rows/ear (16.00 and 16.10 grains/row) in the first and second seasons, respectively. Meanwhile, the lowest ones were recorded by foliar application of mineral fertilization alone with "S.C. 162 " hybrid during both seasons. 
Results presented in Table (5) shows the effect of Nano as foliar application and soil applied mineral fertilization on number of grains/row, number of grains/ear, and 100- grain weight for three yellow maize hybrids and their interaction during 2016 and 2017 seasons.

The data in Table (5) showed that application of nano and mineral fertilizers were, significantly, influenced number of grains/row, number of grains/ear, and 100- grain weight in both growing seasons. The highest values of number of grains/row (40.33 and 42.95 grains), number of grains/ear (709.28 and 754.8 grains), and 100- grain weight (47.33 and $46.52 \mathrm{~g}$ ) were recorded with application of mineral fertilizer in the soil + foliar application of nano- fertilizer followed by foliar nano- fertilization treatment as compared with other treatments. Meanwhile, the lowest ones (34.33 and 37.13 grain/row), (480.62 and 519.82 grains/ear) and (41.33 and $40.67 \mathrm{~g}$ ) were recorded with foliar mineral fertilizer alone during two growing seasons. These results are in agreement with those obtained by Moaveni et al. (2011), Nosser (2011) and Vafa et al. (2015) who stated positive response of crop yield to foliar application of nano- fertilizer. Also, Mekkei and El Haggan (2014) reported that nano- fertilizer increased growth and yield and its components.

Respecting maize hybrids effect on number of grains/row, number of grains/ear, and 100- grain weight, data in Table (5) show significantly differences among the three hybrids in both growing seasons. The hybrid "S.C. 168" recorded the highest values for number of grains/row (38.67 and 41.47 grains), number of grains/ear (569.72 and 610.81 grain/ear), and 100- grain weight (45.35 and $44.38 \mathrm{~g}$ ) while "S.C. 162" hybrid gave the lowest values of number of grains/row (34.67 and 36.62 grains), number of grains/ear, (485.35 and 512.61 grain/ear) and 100- grain weight (40.49 and $38.61 \mathrm{~g}$ ) in two growing seasons. On the other hand, there was no significant difference between "S.C. 166" and "S.C. 162" hybrid on this character in the first season. These differences among hybrids are mainly due to genetic differences makeup between the three cultivars. These results were harmony with those obtained by Khaliq et al. (2009) and Kandil (2013).

The interaction between mineral and nano fertilization and maize hybrids showed a significant effect on number of grains/row, number of grains/ear, and 100- grain weight in the first and second growing seasons (Table 5). Likewise, "mineral fertilizer as soil application with foliar application of nano- fertilizer" or "nano- fertilizer alon" combined with "S.C. 168" hybrid gave the highest mean values of number of grains/row (44.33 and 47.13 grains/row), number of grains/ear
(709.28 and 754.08 grains/ear) and 100- grain weight $(47.33$ and $46.52 \mathrm{~g})$ in the first and second seasons, respectively. With regard to 100 - grain weight, interaction between both nano- fertilizer as foliar application alone or plus with mineral fertilizer as soil application combined with the three varieties in the first season and mineral fertilizer as soil application plus foliar application of nanofertilizer combined with S.C. 166 produced the highest 100- grain weight in the second season. Meanwhile, the lowest ones were recorded by foliar application mineral fertilization alone with "S.C. 162" hybrid during both seasons.

Data in Table (6) showed the effect of foliar application of nano and soil application of mineral fertilization on biological, grain, and straw yields for the studied three yellow maize hybrids and their interaction during 2016 and 2017 seasons.

Table (6) showed that foliar application of nano and soil application of mineral fertilization ( $\mathrm{K}$ and $\mathrm{P}$ ), significantly, influenced biological, grain, and straw yields during both growing seasons. The highest values of biological, grain, and straw yields (18.76 and 17.93 ton/ha.), (8.68 and 8.35 ton/ha.) and (10.08 and 9.58 ton/ha.) were recorded with application of mineral fertilizer in the soil + foliar application of nanofertilizer followed by foliar nano- fertilization treatment as compared with other treatments, respectively. Meanwhile, the lowest ones (14.47 and 13.42 ton/ha.), (6.27 and 6.14 ton/ha) and (8.19 and 7.28 ton/ha.) were recorded with foliar mineral fertilizer alone, respectively during two growing seasons. These results are in agreement with those obtained by El-Bramawy and Shaban (2010), Tarafdar et al. (2014) and Vafa et al. (2015) who stated positive response of crop yield to foliar application of nano- fertilizer. Also, Bakhtiari et al. (2015) indicated that nano-fertilizer; increased wheat grain yield and its components. Nano- chalate zinc application expressed a positive effect on yield and yield components. For instance, soil application of nanochalate zinc produced the highest 100-grain weight and seed yield (Mosanna and Behrozyar, 2015). Significant increase was recorded on yield attributes of faba bean using foliar application of nano- fertilizer in both growing seasons (Gomaa et al., 2016).

Data in Table (6) show significantly differences among the three hybrids on biological, grain, and straw yields in both growing seasons. The hybrid "S.C. 168" recorded the highest values for biological, grain, and straw yields (17.65 and 15.94 ton/ha.), ( 7.84 and 7.57 ton/ha.) and (9.81 and 8.37 ton/ha.) while "S.C. 162" hybrid gave the lowest values of number of grains/row, number of grains/ear, and 100- grain weight (14.64 and 14.02 ton/ha.), (6.53 and 6.41 ton/ha.) and (8.11 and 
7.61 ton/ha.) in both seasons, respectively. On the other hand, there was no significant difference between "S.C. 166 " and "S.C. 162" hybrid on this character in the first season. These differences among hybrids are mainly due to genetic differences makeup between the three cultivars. These results were harmony with those obtained by Khaliq et al. (2009), Nosser (2011), Kandil
(2013) and Gomaa et al. (2016) who showed that significant between maize hybrids.

The interaction between mineral and nano fertilization and maize hybrids showed a significant effect on biological, grain, and straw yields in the first and second growing seasons (Table 6).

Table 5. Plant attributes of three maize hybrids as influenced by soil and foliar mineral and nanofertilizer and their interaction during 2016 and 2017 seasons

\begin{tabular}{|c|c|c|c|c|c|c|c|c|}
\hline \multirow{3}{*}{$\begin{array}{c}\text { Plant } \\
\text { attribute }\end{array}$} & \multirow{3}{*}{$\begin{array}{l}\text { Treatments } \\
\text { A). Foliar and soil application }\end{array}$} & \multirow{2}{*}{\multicolumn{3}{|c|}{$\begin{array}{c}\text { Season } 2016 \\
\text { B). Maize hybrids } \\
\end{array}$}} & \multirow{3}{*}{$\begin{array}{c}\text { Mean } \\
\text { (A) }\end{array}$} & \multicolumn{3}{|c|}{ LSD at 0.05} \\
\hline & & & & & & \multirow[t]{3}{*}{$\mathbf{A}$} & \multirow[t]{2}{*}{ B } & \multirow[t]{2}{*}{$A \times B$} \\
\hline & & S $C 162$ & $S C 166$ & $\mathrm{~S} C 168$ & & & & \\
\hline \multirow{12}{*}{$\begin{array}{l}\text { Number of } \\
\text { grains/row }\end{array}$} & \multicolumn{5}{|c|}{ Season 2016} & & & \multirow{6}{*}{4.06} \\
\hline & Mineral fertilizer as foliar & 30.67 & 30.33 & 34.33 & $31.78 d$ & \multirow{5}{*}{1.21} & \multirow{5}{*}{2.03} & \\
\hline & Mineral fertilizer as soil & 36.33 & 38.00 & 35.67 & $36.67 \mathrm{c}$ & & & \\
\hline & Nano- fertilizer as foliar & 36.00 & 40.33 & 40.33 & $38.89 \mathrm{~b}$ & & & \\
\hline & Mineral as soil + Nano foliar & 35.67 & 41.00 & 44.33 & $40.33 a$ & & & \\
\hline & Mean $(B)$ & $34.67 \mathrm{~b}$ & $37.42 a$ & $38.67 a$ & & & & \\
\hline & \multicolumn{5}{|c|}{ Season 2017} & \multirow{6}{*}{1.05} & \multirow{6}{*}{1.87} & \multirow{6}{*}{3.75} \\
\hline & Mineral fertilizer as foliar & 30.60 & 31.87 & 37.13 & $33.20 \mathrm{~d}$ & & & \\
\hline & Mineral fertilizer as soil & 39.13 & 40.80 & 38.47 & $39.47 \mathrm{c}$ & & & \\
\hline & Nano- fertilizer as foliar & 38.80 & 43.10 & 43.13 & $41.68 b$ & & & \\
\hline & Mineral as soil + Nano foliar & 37.93 & 43.80 & 47.13 & $42.95 \mathrm{a}$ & & & \\
\hline & Mean $(B)$ & $36.62 b$ & 39.90а & $41.47 a$ & & & & \\
\hline \multirow{12}{*}{$\begin{array}{l}\text { Number of } \\
\text { grains/ear }\end{array}$} & \multicolumn{5}{|c|}{ Season 2016} & \multirow{5}{*}{42.33} & \multirow{5}{*}{51.43} & \multirow{5}{*}{102.87} \\
\hline & Mineral fertilizer as foliar & 429.38 & 424.62 & 480.62 & $444.87 d$ & & & \\
\hline & Mineral fertilizer as soil & 508.62 & 532.00 & 524.35 & $521.66 c$ & & & \\
\hline & Nano- fertilizer as foliar & 504.00 & 564.62 & 564.62 & $544.41 b$ & & & \\
\hline & Mineral as soil + Nano foliar & 499.38 & 627.30 & 709.28 & $611.99 a$ & & & \\
\hline & Mean $(B)$ & $485.35 c$ & $537.14 b$ & $569.72 a$ & & \multirow{7}{*}{29.15} & \multirow{7}{*}{34.90} & \\
\hline & \multicolumn{5}{|c|}{ Season 2017} & & & \\
\hline & Mineral fertilizer as foliar & 428.40 & 446.18 & 519.82 & $464.80 c$ & & & \\
\hline & Mineral fertilizer as soil & 547.82 & 571.20 & 565.51 & $561.51 b$ & & & 69.81 \\
\hline & Nano- fertilizer as foliar & 543.20 & 603.82 & 603.82 & $583.61 b$ & & & \\
\hline & Mineral as soil + Nano foliar & 531.02 & 670.14 & 754.08 & $651.75 a$ & & & \\
\hline & Mean $(B)$ & $512.61 c$ & $572.84 b$ & $610.81 a$ & & & & \\
\hline & & & Seas & 2016 & & & & \\
\hline & Mineral fertilizer as foliar & 35.67 & 37.13 & 41.33 & $38.04 b$ & & & \\
\hline & Mineral fertilizer as soil & 38.34 & 36.67 & 46.72 & $40.58 b$ & 3.48 & 2.47 & 4.94 \\
\hline & Nano- fertilizer as foliar & 43.15 & 46.54 & 46.00 & $45.23 a$ & & & \\
\hline & Mineral as soil + Nano foliar & 44.80 & 43.74 & 47.33 & $45.29 a$ & & & \\
\hline 100- grain & Mean $(B)$ & $40.49 b$ & $41.02 b$ & $45.35 a$ & & & & \\
\hline weight (g) & & & Seas & 2017 & & & & \\
\hline & Mineral fertilizer as foliar & 36.23 & 37.00 & 40.67 & $37.97 c$ & & & \\
\hline & Mineral fertilizer as soil & 37.55 & 44.91 & 46.02 & $42.83 b$ & 2.62 & 1.39 & 2.77 \\
\hline & Nano- fertilizer as foliar & 38.00 & 39.67 & 44.29 & $40.65 b$ & & & \\
\hline & Mineral as soil + Nano foliar & 42.67 & 49.91 & 46.52 & $46.37 a$ & & & \\
\hline & Mean (B) & $38.61 \mathrm{c}$ & $42.87 \mathrm{~b}$ & $44.38 a$ & & & & \\
\hline
\end{tabular}

Mean values in the same column/row marked with the same letter are not significantly different at 0.05 level of probability. 
Table 6. Plant attributes of three maize hybrids as influenced by soil and foliar mineral and nano- fertilizer and their interaction during 2016 and 2017 seasons

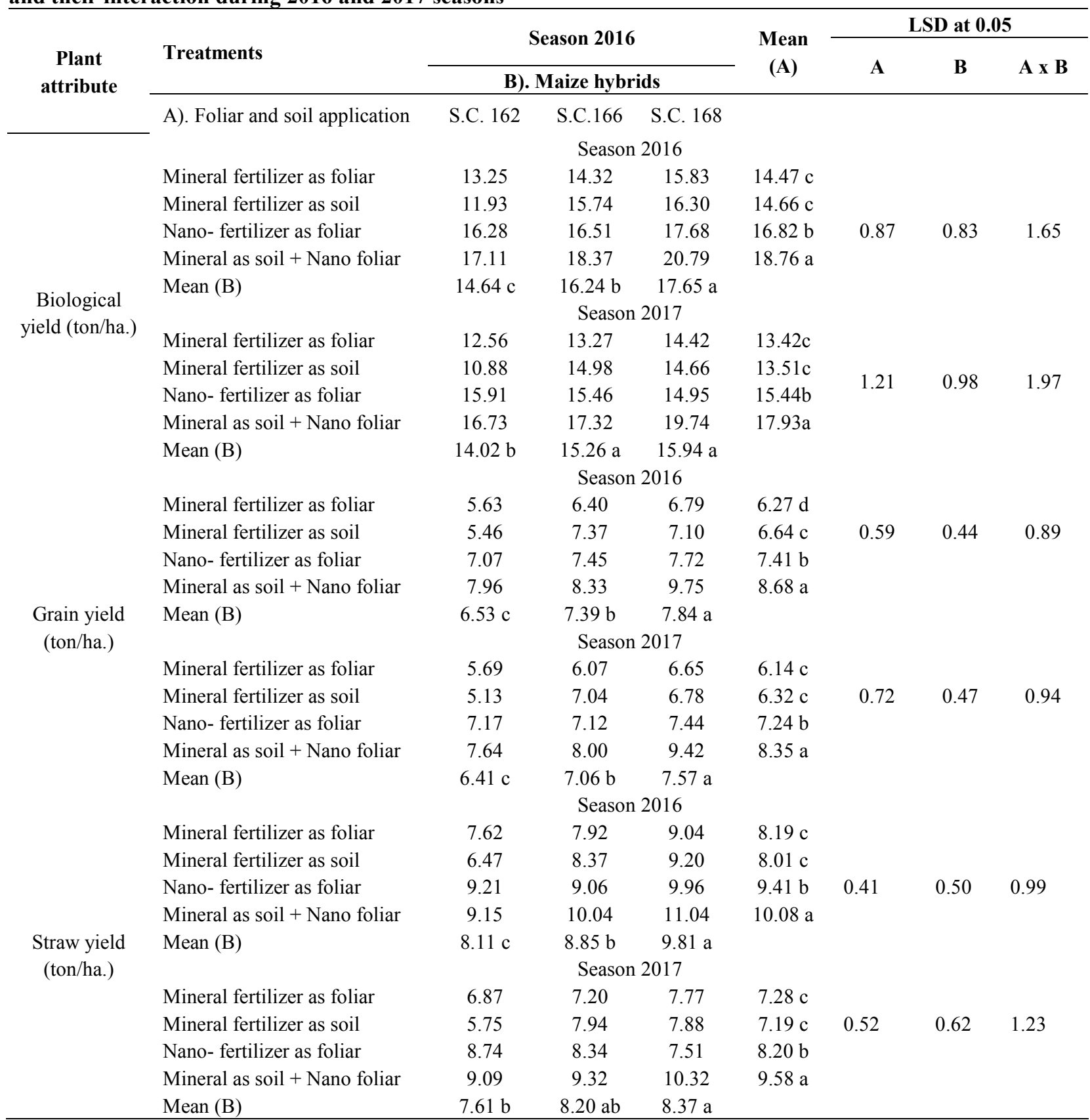

-Mean values in the same column/row marked with the same letter are not significantly different at 0.05 level of probability.

Likewise, "mineral fertilizer as soil application with foliar application of nano- fertilizer" or "nano- fertilizer alon" with "S.C. 168" hybrid gave the highest mean values of biological, grain, and straw yields (20.79 and 19.74 ton/ha.), (9.75 and 9.42 ton/ha.) and (11.04 and 10.32 ton/ha.) in two seasons, respectively. Meanwhile, the lowest ones were recorded by foliar application mineral fertilization alone with "S.C. 162" hybrid during both seasons.

\section{CONCLUSION}

It was concluded form the present results that sowing maize hybrid S.C. 168 combined with foliar application of Nano- fertilizers ( $\mathrm{K}$ and $\mathrm{P}$ ) and mineral fertilization by $\mathrm{K}$ and $\mathrm{P}$ in soil; increased yield and its components of maize crop. 


\section{REFERENCES}

Al-Amin, M.D., and H.P. Jayasuriya. 2007. Nanotechnology prospects in agricultural context: An overview. In: proceedings of the International Agricultural Engineering Conference, 3-6 December, Bangkok, 548.

Anonymous, A. A. 2009. Nano Technology in Agriculture. J. Agric. and Technology.114, 54-655.

Bakhtiari, Mitra, P. Moaveni, and B. Sani. 2015. The effect of iron nanoparticles spraying time and concentration on wheat. Biol. Forum Int. J., 7(1):679-683.

CoStat Ver. 6.311. 2005. Cohort software798 light house Ave. PMB320, Monterey, CA93940, and USA. email: info@cohort.com and Website: http://www.cohort.com/DownloadCoStatPart2.html

El-Bramawy, M.A.S.A., and W.I. Shaban. 2010. Effects potassium fertilization on agronomic characters and resistance to chocolate spot and rust diseases in faba bean. Tunisian J. Plant Protection 5(2): 131-150.

F.A.O. 2014. Food and Agriculture Organization Statistics, FAOSTAT. www.fao.org/faostat.

Farnia, A.,and M. M. Omidi. 2015. Effect of Nano-Zinc Chelate and Nano-Biofertilizer on Yield and Yield Components of Maize (Zea Mays L.), Under Water Stress Condition. Indian J. Nat. Sci., 5(29):4614-46.

Gerpacio, V. R., and P. L. Pingali. 2007. Tropical and subtropical maize in Asia: Production systems, constraints and research priorities. Mexico, D.F.: CIMMYT. 93 pp.

Gholami, A., M. Taghizadeh, and N. Moalemi. 2013. The scrutiny of interaction between iron nano chelate and chlophony hydrogel on soil chemical and nutritional properties. J Nov. Appl. Sci., 2 (8): 214-218.

Gomaa, M. A., E. E. Kandil, A. A. Abuo Zeid, and B. M. A. Salim. 2016. Response of some faba bean varieties to fertilizers manufactured by nanotechnology. J. Advan. Agric. Resh., 21 (3):384.399.

Gomez, A. K., and A. A. Gomez. 1984. Statistical procedures for agricultural research. ( $2^{\text {nd }}$ edition). John Wiley and Sons. New York.

Jackson, M. L. 1976. Soil Chemical Analysis. Constable and Co. L.T.P., London, England.

Kandil, E.E. 2013. Response of some maize hybrids (zea mays 1.) to different levels of nitrogenous fertilization. J. Appl. Sci.Resh., 9(3): 1902-1908.

Kandil E. E., E. A. O. Marie. 2017. Response of some wheat cultivars to nano-, mineral fertilizers and amino acids foliar application. Alex. Sci. Exch. J.,38(1):53-68.
Khaliq, T., A. Ahmad, A. Hussain, and M.A. Ali. 2009. Maize hybrids response to nitrogen rates at multiple locations in semiarid environment. Pak. J. Bot., 41(1): 207-224.

Klute, A. 1986. Methods of Analysis. Part 1, Soil Physical Properties. ASA and SSSA, Madison, WI.

Kulzer, F., and M. Orrit. 2004. Single-molecule optics. Annu Rev Phys. Chem., 55:585-611.

Mekkei, M. E. R., and E. A. M. El Haggan. 2014. Effect of $\mathrm{Cu}, \mathrm{Fe}, \mathrm{Mn}$ and $\mathrm{Zn}$ foliar application on productivity and quality of some wheat cultivars (Triticum aestivum L.) J. Agri-Food \& Appl. Sci., 2 (9): 283-291.

Minjian, C., Y. Haiqui, Y. Hongkui, and J. Chungi. 2007. Difference in tolerance to potassium deficiency between maize inbred lines. P1. Prod.Sci. 10(1): 42-46.

Moaveni, P., A. H. Talebi, A. Farahani, and K. Maroufi. 2011. Study of nano particles $\mathrm{TiO} 2$ spraying on some yield components in barley (Hordem vulgare L.). Int. Conf. Environ. Agric. Engineering.119-115.

Mosanna, R., and E. K. Behrozyar. 2015. Morphophysiological response of maize (Zea mays L.) to zinc nano-chelate foliar and soil application at different growth stages. J. on New Biol. Rept. 4(1) 46 - 50.

Naderi, M. R., and A. D. Shahraki. 2013. Nanofertilizers and their roles in sustainable agriculture. Int. J. Agri. Crop Sci., 5 (19), 2229-2232.

Nosser M. A. 2011. Effect of some foliar application on yield and its components in broad bean (Vicia faba, L.). Egypt. J. Agric. Res., 89 (3):1071-1087.

Subbarao, C. V., G. Kartheek, and D. Sirisha 2013. "Slow Release of Potash Fertilizer Through Polymer Coating". Inter. J. Appl. Sci. and Engin.,11(1): 25-30.

Sultan, Y., R. Walsh, C.M. Monreal, and M.C. DeRosa. 2009. Preparation of functional aptamer films using layer-bylayer self-assembly, Biomacromolecules J. 10:1149-1154.

Tarafdar, J. C., R. Raliya, H. Mahawar, and I. Rathore. 2014. Development of zinc nanofertilizer to enhance crop production in pearl millet (Pennisetum americanum). Agric. Res. J. 3(3):257-262.

Vafa, Z. N., A. R. Sirousmehr, A. Ghanbari, I. Khammari, and N. Falahi. 2015. Effects of nano zinc and humic acid on quantitative and qualitative characteristics of savory (Satureja hortensis L.). Intern. J. Biosci., 6(3):124-136.

Zhang, Q., and G. Wang. 2005. Studies on nutrient uptake of rice and characteristics of soil microorganisms in a longterm fertilization experiments for irrigated rice. Zhejiang Univ. Sci., 6(2):147-152. 


\section{الملخص العربي}

\section{مقارنة استجابة بعض هجن الأرة الثامية الحديثة للتسميد المعدني وبعض أسمدة النانو}

محمود عبد العزيز جمعة، فتحي ابر اهيم رضوان، عصام إسماعيل قنديل، ضرغام هام هادي حسن الجلابي لهي

أجريت تجربتان حقليتان في مزرعة كلية الزراعة(سابا أوضحت النتائج ما يلي:

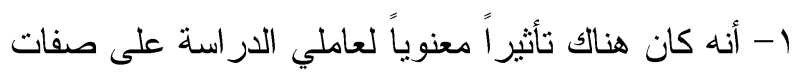

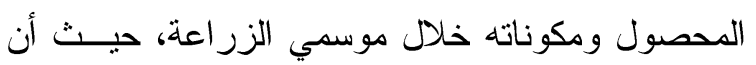

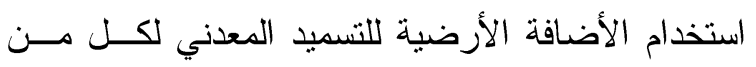

السماد الفوسفوري و البوتاسي + الرش الإرضي الورقي بسمادي

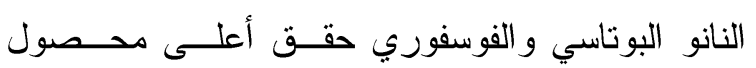

ومكوناته و الحصول علي أفضل القيم للصفات التي تـــم

$$
\text { دراستها. }
$$

r- أختلفت الثلاثة هجن من الذرة الثامية إختلافاً معنويـاً

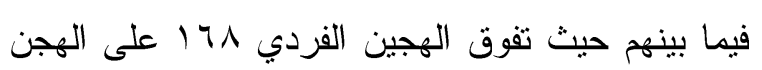

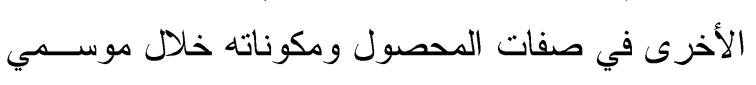

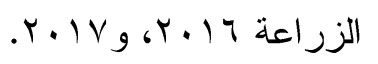

r- كان التداخل معنوياً بين هجن الذرة الثامية ومعاملات

$$
\text { الأسمدة المعدنية و النانوية في موسمي الدر اسة. }
$$

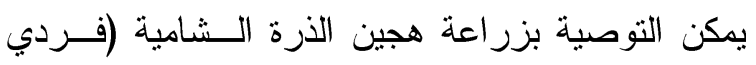

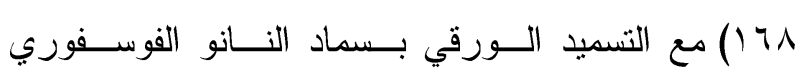
و البوتاسي + الأضافة الأرضية للسماد المعدني الفوسفوري لـوني

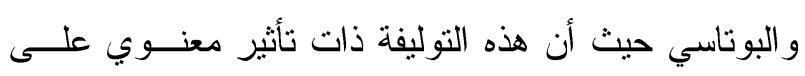
المحصول ومكوناته تحت الظروف البيئة لمنطقة الدراسة.

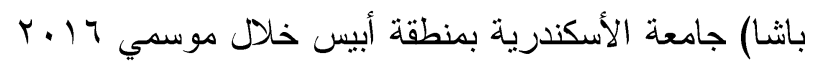
و r.lV لدراسة أستجابة بعض هجن الذبة الذرة الثامية الصفر اء الحديثة للتسميد المعدني وبعض أسمدة النانو .

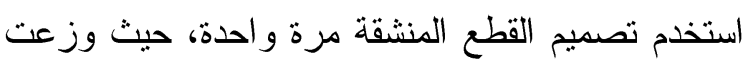

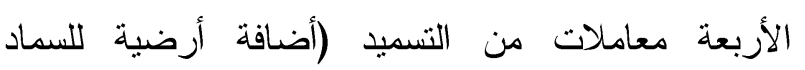

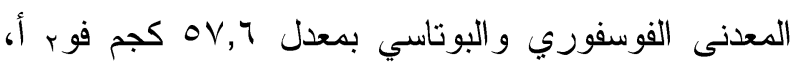

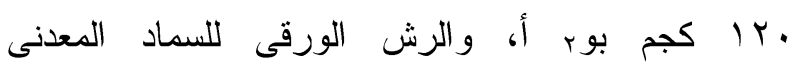

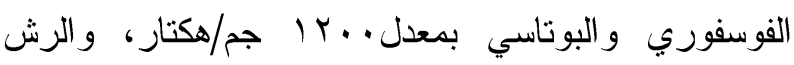

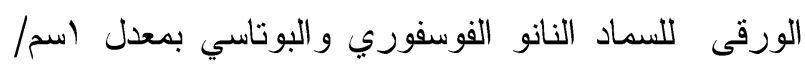

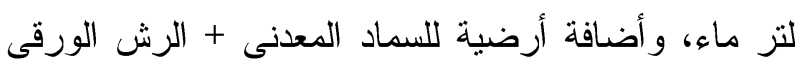

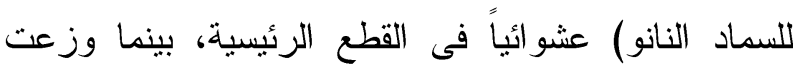

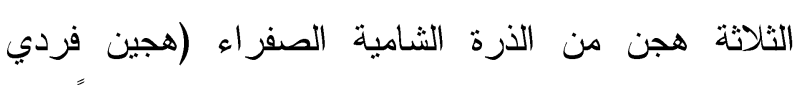

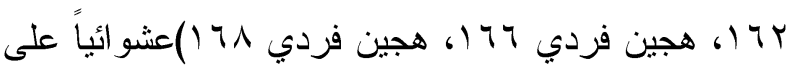
القطع الثقية فى ثلاث مكررات.

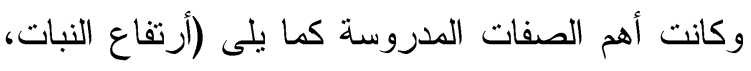

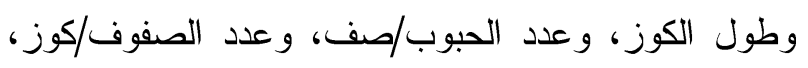

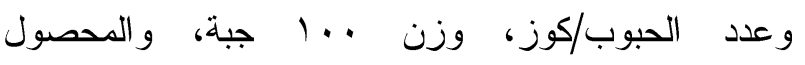

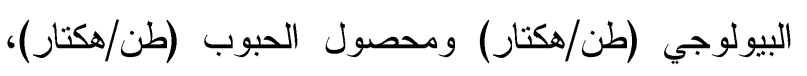
ومحصول القش بالطن/هكتار). 